\title{
The Concentrations of Cholesterol and Reproduction Hormones in Serum of Rabbits Doe That Consumed Moringa oleifera Leaf Extracts
}

\author{
Setiasih $^{1}$, Sri Wahjuningsih ${ }^{2}$, Sri Winarsih ${ }^{3}$, Hendrawan Soetanto $^{4}$ \\ ${ }^{1}$ Institute Assessment of Agriculture Technology East Java, Indonesia Agricultural Research and Development Agency, Indonesia \\ ${ }^{2,4}$ Animal Husbandry Faculty, University of Brawijaya, Malang, Indonesia \\ ${ }^{3}$ Medical Faculty, University of Brawijaya, Malang, Indonesia
}

\begin{abstract}
This study was conducted to examine the effect of various kinds of Moringa leaf extracts on cholesterol, estradiol, FSH, LH levels and litter size in rabbit does. The extracts used were hexane fraction extract (HeEF), ethanol fraction extract (EtEF) and ethanol rough extract (EtCE) from moringa leaf flour. Seven treatments were administered including extracts in pellets at a dose of $0,0.13 \% \mathrm{HeEF}, 0.26 \% \mathrm{HeEF}, 0.37 \mathrm{EtEF}, 0.74 \% \mathrm{EtEF}, 0.54 \% \mathrm{EtCE}$ and $1.08 \%$ EtCE. Each treatment was reduplicated on 4 rabbits. Cholesterol levels, estradiol, LH and FSH blood serum, mating readiness and litter size were measured, which results showed that the treatment significantly $(\mathrm{P}<5 \%)$ lowered the cholesterol level and increased the estradiol level in blood serum. On the other hand, the treatment had no significant effect on FSH, LH and litter size levels except at LH levels 2 hours after mating.
\end{abstract}

KEY WORDS: Cholesterol, Estradiol, Estrogen, FSH, LH, Rabbit, Moringa Leaf Extract.

\section{INTRODUCTION}

Reproductive performance of livestock can be enhanced by providing alternative high nutrient feeds that contain secondary metabolite compounds such as phytoestrogens that improve the reproductive functions in the body. Phytoestrogens are a group of natural bioactive compounds found in plants that share similar structure and function as estradiol in mammals. Other types of phytoestrogens include isoflavones, lignans and coumestrol. Phytosterols are also referred to as phytoestrogens because the structure is similar to cholesterol which is a precursor of estradiol [1]. Isoflavones are hydrolyzed by microflora in the intestine into p-ethylphenol and equol which then interact with receptors in the nucleus namely ER $\alpha$ and $\operatorname{ER} \beta$ through genomic and non-genomic pathways [2].

The use of phytoestrogens still remains a controversy for it brings different effects. This problem might occur due to available publications about the effect of phytoestrogens on reproduction are written based on only laboratory animals or experimental animals, especially the rodentia group. The results of these studies indicate the effect of phytoestrogens on animal fertility, yet the development varies, in which both positive and negative impacts are present due to the biological response of phytoestrogens in animals depending on factors such as species, age, sex, dosage, method of administration, and metabolism and the reproductive phase [1];[3]. Some parts of Moringa plant have been reported to contain phytoestrogens, namely isoflavones or phytosterols.

The presence of phytosterol compounds in moringa leaf flour due to processing methods. The highest phytosterol content was found in moringa leaf flour with the initial treatment of steamed blanching containing $348.05 \mathrm{ppm}$ cholesterol, $2410 \mathrm{ppm}$ stigmasterol and $3321.17 \mathrm{ppm} \beta$-sitosterol [4]. Moringa leaves are rich in flavonoids, including isoflavones. The presence of flavonoid compounds in moringa leaf water extracts namely quercetin and kaemferol but no isoflavone compounds were found [5]. The identification of phytosterol compounds (lathosterol, campesterol, stigmasterol and $\beta$-sitosterol) and isoflavones (daidzein, formononetin, biocanin A and glycitein) in Moringa leaf extract [6].

Some prior studies have reported the effect of consuming the leaves and other parts of Moringa oleifera, Lam) on reproduction system. Moringa leaf has been reported to have a lactation booster effect (galactagogue) which increases the milk production in humans and in wistar rats [7];[8];[4]. The administration of Moringa leaves gave a better effect on the fertility and litter size of rabbits than those fed Cajanus cajan and Centrosema pubescen [9]. On the contrary, the negative effect of consuming Moringa leaves on reproduction for it gave antifertility effect which can inhibit implantation and cause abortion in mice [10]. Antifertility is also found in the roots and bark of Moringa stem and in Moringa seeds [11]. A positive effect, in which supplementation of 20\% moringa leaf flour in rabbits had the best effect on reproductive performance parameters, namely litter size, birth weight and milk production interpreted from weaning weight and mortality [12];[13]. 


\section{International Journal of Current Science Research and Review}

ISSN: 2581-8341

Volume 04 Issue 12 December 2021

DOI: 10.47191/ijcsrr/V4-i12-13, Impact Factor: 5.825

IJCSRR@ 2021

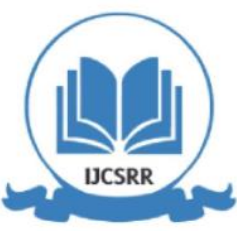

WWW.ijcsrr.org

The information above shows that the effect Moringa leaves on livestock reproduction is influenced by bioactive substances and livestock physiology phase. The purpose of this study was to determine the effect of Moringa leaf extract extracted using different solvents on the levels of cholesterol, estradiol, FSH, LH and litter size of rabbit does.

\section{MATERIAL AND METHOD}

A total of 28 New Zealand White breeds proven rabbits which weights ranged from 2.1 - $2.8 \mathrm{~kg}$ and 7 New Zealand White crossbreed male weighing between 2.4-2.9 kg were used in this study. Rabbits Doe were divided into four groups based on average body weight of $2.1 \mathrm{~kg}$ (group I), $2.35 \mathrm{~kg}$ (group II), $2.64 \mathrm{~kg}$ (group III), and 2.85 (group IV). Three types of extracts were used in this study including hexane fraction extract (HeEF), ethanol fraction extract (EFE) and crude ethanol extract (EtCE). Each extract was tested at two levels equivalent to the addition of $10 \%$ and $20 \%$ of Moringa leaf flour in concentrate feed, resulting in seven treatments administered in this study, namely the addition of concentrate feed with Moringa leaf extract 0 (control), $0.13 \mathrm{HeEF}, 0.26 \% \mathrm{HeEF}$, 0.37 EFE, 0.74 EFE, 0.54\% EtCE, and 1.08\% EtCE. A RCBD (Randomized Complete Block Design) experiment with seven treatments and four replications was administered.

Concentrate feed and forage feed were used in this experiment. Concentrate feed was given as much as $2 \%$ of body weight, while forage feed (broccoli leaf) was given as an adlibitum.

Concentrate feed has been started 5 days before doe mating, and was stopped after mating. After the mating up to giving birth, control feed (without extracts) was given to avoid abortion due to phytoestrogens. After giving birth, does were feed with concentrate feed again.

The variables observed in this study were cholesterol levels, estradiol 17- $\beta$, lutheinizing hormone (LH), and follicle stimulating hormone (FSH) in rabbit blood serum, mating accepted, pregnancy rate and litter size of rabbit does.

Blood samples were obtained from the ventral veins in rabbit ears 2 days before mating, 2 hours after mating and the 15th day of lactation to measure cholesterol, estradiol, LH and FSH in the blood. Blood sampels were taken in a non-EDTA venoject tube and then brought to the laboratory for serum extraction to be later analyzed. Blood cholesterol levels were measured based on enzymatic methods using the 'Bio System' reagent and the cholesterol oxidase / peroxidase enzyme.

The concentrations of estradiol, FSH and LH in blood serum were measured using Enzyme Linked Immunosorban Assay (ELISA) using Elabscience Elisa kits namely rabbit LH (Lutheiizing Hormone) Elisa Kit Elabsciense, catalog No: E-EL_RB0832, Estradiol (E2) Elisa kit No, Elisa Kit No rabbit . E-EL-0065, Rabbit FSH (Follicle-Stimulating Hormone) Elisa kit catalog No, EEL-RB2044. The measurement of cholesterol level was carried out at the Clinical Pathology Laboratory. The levels of the FSH hormones, LH and estradiol were measured at the Physiology Laboratory of the Faculty of Medicine, University of Brawijaya, Jl. Veteran, Malang, Indonesia.

The data obtained were analyzed using SPSS version 23 (IBM, Harvard University) using a Randomized Variance Design Group analysis. If a meaningful difference was found, LSD test would be peformed.

\section{RESULTS AND DISCUSSIONS}

\section{Cholesterol and Estradiol 17- $\beta$ Level in the Blood Serum}

Figure 1. Shows the effect of moringa leaf extract added in the feed in decreasing the level of cholesterol in the blood serum of the rabbits.

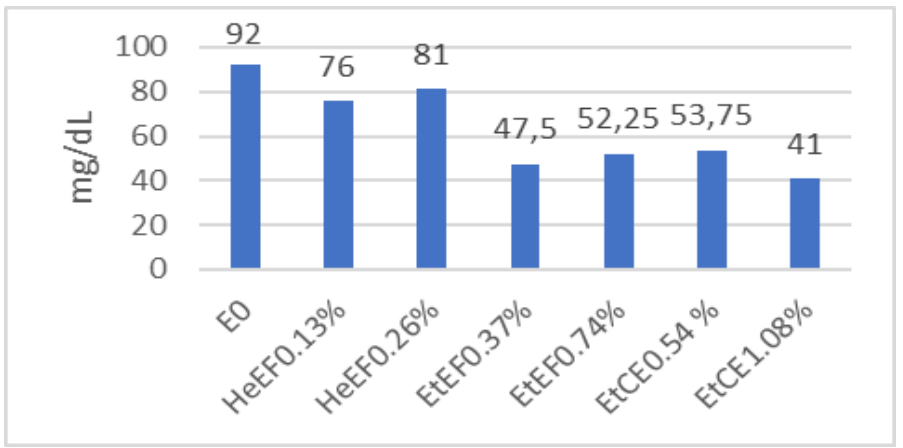

Figure 1. Concentration of cholesterol in Rabbit Doe serum at days 15 lactation 


\section{International Journal of Current Science Research and Review}

ISSN: 2581-8341

Volume 04 Issue 12 December 2021

DOI: 10.47191/ijcsrr/V4-i12-13, Impact Factor: 5.825

IJCSRR@ 2021

WWw.ijesrr.org

Table 1. Shows that the decrease in total cholesterol occurred due to Moringa leaf extract added in the feed. The normal total cholesterol levels in rabbits range between 10-80 mg / dL (Rosenthal, 2002). The use of pellet feed without extracts (control) shows blood serum cholesterol levels that exceeded the normal limit of $92 \mathrm{mg} / \mathrm{dL}$, possibly due to excess dietary fat than needed. The addition of Moringa leaf flour extract has made the cholesterol level become normal.

In the HeEF treatment of $0.13 \%$ and $0.26 \%$, insignificant decreases were found. Cholesterol levels decreased significantly in EtEF by $0.37 \%$ and $0.74 \%$ and EtCE by $0.54 \%$ and $1.08 \%$. The decreases might be affected by the effect of phytosterols on HeEF and EtCE, whereas EtEF has no significant effect on the lower cholesterol levels because the amount of the phytosterol content has been minimized in EtEF.

The lower cholesterol level found in blood serum might be due to the conflicting roles of phytosterols and cholesterol in absorption process in the intestine. Xinmei, et al. (2015)reported that sterol compounds in feed can reduce Low Density Lipoprotein (LDL). By increasing the intake of phytosterols, the absorption of cholesterol and stanol decreases. Increased phytosterol and stanol supplementation can reduce LDL and total cholesterol but they have no influence on the High Density Lipoprotein (LDL) and Triglycerides (TG). This goes consistently with the report of Ara, et al. stating that Moringa seed flour reduces cholesterol and glucose levels in rat blood [14]. According to Anwar and Bahger, Moringa seeds are part of the Moringa plants that contain the highest amount of phytosterols.

Moringa leaf feed can affect the chemical contents in the blood of mice, in which the amont of urea, albumin, globulin, ALT, ALP, AST are higher, while the levels of creatine, total cholesterol, triglycerides, LDL are reduced [15]. The feed had no effect on total protein, total bilirubin and HDL. Sandoval dan Jimeno (2013) further reported that Moringa leaf capsules with a dose of 350 mg per capsule, 2 capsules three times a day for 30 days reduce LDL cholesterol in adults with LDL> $2.6 \mathrm{mmol} / \mathrm{L}$ (> $100 \mathrm{mg} / \mathrm{dL}$ ) and reduce the risk of cardiovasculary diseases.

Phytosterols and phytostanols can reduce cholesterol levels by inhibiting the absorption of cholesterol in the intestine, avoiding cholesterol in bile micelles, increasing the excretion of bile salts or inhibiting esterification of cholesterol in the intestinal mucosa and co-crystallization of phytosterols and cholesterol [16]. Phytosterolization of cholesterol and cholesterol in the gastrointestinal tract causes a decrease in intestinal cholesterol uptake because the crystalline solubility is lower than the cholesterol solubility. Furthermore the decrease in cholesterol levels occurred due to lower amounts of hydroxy enzyme methylglutaryl-CoA synthetase, methylglutaryl-CoA reductasehydroxy enzyme, farnesildyphosphatesynthetase enzyme with the influence of stigmasterol. Stigmasterol is one phytosterol compounds found in Moringa leaf flour extract [17].

Cholesterol is a compound needed in the metabolism system. Cholesterol a precursor in the synthesis of steroid hormones (steroidogenesis) such as estradiol, progesterone and testosterone [18].

\section{The concentration of estradiol 17- $\beta$ and mating accepted of does}

Table 1 presents the estradiol levels of 17- $\beta 2$ days before mating, mating accepted, and pregnancy rate of rabbit does.

Table 1. Estradiol 17- $\beta$ level and mating accepted and of does pregnancy rate

\begin{tabular}{llll}
\hline Treatments & $\begin{array}{l}\text { Estradiol 17- } \beta, 22 \\
\text { before mating }(\mathrm{pg} / \mathrm{mL})\end{array}$ & $\begin{array}{c}\text { Mating accepted } \\
(\%)\end{array}$ & $\begin{array}{l}\text { Pregnancy Rate } \\
(\%)\end{array}$ \\
\hline E0 & $219.17 \pm 70.42^{\mathrm{a}}$ & 75 & 50 \\
HeEF0.13\% & $217.71 \pm 60.34^{\mathrm{a}}$ & 75 & 25 \\
HeEF0.26\% & $444.48 \pm 83.13^{\mathrm{b}}$ & 100 & 75 \\
EtEF0.37\% & $346.52 \pm 79.18^{\mathrm{ab}}$ & 50 & 50 \\
EtEF0.74\% & $302.47 \pm 81.76^{\mathrm{ab}}$ & 75 & 25 \\
EtCE0.54\% & $380.20 \pm 12.48^{\mathrm{ab}}$ & 75 & 75 \\
EtCE1.08\% & $391.11 \pm 15.37^{\mathrm{ab}}$ & 75 & 50 \\
\hline
\end{tabular}

${ }^{*}$ Different notifications in the same column show significant differences $(\mathrm{P}<5 \%)$ 


\section{International Journal of Current Science Research and Review}

ISSN: 2581-8341

Volume 04 Issue 12 December 2021

DOI: 10.47191/ijcsrr/V4-i12-13, Impact Factor: 5.825

IJCSRR@ 2021

www.ijcsrr.org

It can be seen in Table that use of Moringa leaf extract affects the hormone estradiol level 2 days before mating. This $17-\beta$ estradiol level is a combination of endogenous estradiol produced by the ovaries and the ones affixed due to the influence of phytoestrogens in the form of isoflavones or phytosterols in the concentrate feed. Estradiol levels of 17- $\beta$ that is influenced by isoflavones and phytosterols in this study could not be measured because livestock were not subject to ovariectomy.

Based on Table 3, the HeEF level that increased from $0.13 \%$ to $0.26 \%$ caused $17-\beta$ estradiol levels to increase from $217.71 \pm$ 60.34 to $444.48 \pm 83.13 \mathrm{pg} / \mathrm{mL}$. Higher levels of estradiol $17-\beta$ also occurred when EtCE extracts were increased, but did not occur when the level of EtEF increased. The differenct effects of different extracts may be due to different types and content of estrogenic compounds. HeEF contains phytosterols, EtCE contains phytosterols and isoflavones whereas ETEF only contains isoflavones [6]. Phytosterols are compounds that have cholesterol-like structures found in animals which are the precursors of the estradiol hormone. Although Moringa leaf extract reduces cholesterol, as a precursor ingredient of estradiol, it is suspected that the addition of phytosterol compounds in $\mathrm{HeEF}$ and EtCE can replace it as a precursor to form estradiol (steroidogenesis).

Estradiol 17- $\beta$ hormone levels have been reported to be associated with mating readiness. According to Gomez, et al., (2008) the readiness to mate in female rabbit is seen from the color and swelling in the vulva. The color of the vulva is classified into several colors namely pale, pink, red and purple, while swelling is seen based on wheter the vulva is swollen or not. Rabbits that have high mating readiness have red and swollen vulva. If such condition does not occur, the rabbits are not ready to mate or if they mated, the success rate would be very low.

Ubilla and Ebollar found the highest concentrations of estradiol in non-pregnant lactating rabbits on day 1, 5, 7 and 23 to 30 after giving birth. The lowest estradiol concentrations occur on day 13 to 23 post-birth.

It can be inferred from Table 3 that the treatments increased the estradiol level 2 days before mating (> $350 \mathrm{pg} / \mathrm{mL})$. The vulva also looked red and swollen due to hyperemia level that reached $75 \%$ in the HeEF treatment $0.26 \%$, EtCE $0.54 \%$ and EKE $1.08 \%$. This affected the readiness to mate with males.

\section{The Concentrations of FSH and LH in the Serum}

Table 2 shows the concentrations of FSH and LH in the serum and litter size of rabbit does.

The treatments did not affect the FSH level at 2 hours before mating and on the 15th day of the lactation period. However, the treatment caused significantly different FSH level 2 hours after mating in EtCE treatment by $1.08 \%$ and HeEF by $0.26 \%$.

FSH hormone level affects the number of follicles in the ovary. Based on Figure 2, it can be seen that the administration of Moringa leaf flour extract increased FSH level. Higher extract dose brought higher FSH level. FSH level that exceeded 40 mIU occured in the HeEF treatment by $0.26 \%$, EtEF by $0.74 \%$, EtCE by $0.54 \%$ and EKE by $1.08 \%$.

The administration of Moringa leaf flour affected the thickness of the uterine epiderma wall but did not significantly affect the levels of the LH and FSH hormones in rats [19]. The FSH hormone is a hormone help form the follicles in the ovaries.

Table 3. Presents that the highest LH concentration occurs at 2 hours after mating when compared to 2 days before mating. This occurs because in rabbits, LH is secreted by the anterior pituitary gland regulated by hypothalamus due to stimulation in the form of copulation. Then, ovulation will occur 10 hours after copulation [20].

Different responses were found in the treatment of Moringa leaf extract in LH levels 2 days before mating and 2 hours after mating. In 2 days before mating, Moringa leaf extract extract significantly affected $(\mathrm{P}<0.05)$ the LH level at the highest in $0.54 \%$, EKE treatment at $50.50 \pm 16.27 \mathrm{mIU} / \mathrm{mL}$ and the lowest in the ETEF $0.37 \%$ treatment at $17,65 \pm 5.70 \mathrm{mIU} / \mathrm{mL}$. In 2 hours after mating, there was a tendency for an increase in LH levels due to Moringa leaf flour extract treatment. However the increase was not statistically significantly different. Whereas at the time of lactation, the treatment did not significantly affect LH level in the blood serum.

According to Muelas et al. (2007), there was a significant difference between LH concentrations measured 2 hours before or after mating (5.1 and $5.4 \mathrm{ng} / \mathrm{mL}$, respectively) compared to 2 hours after mating $(29.0 \mathrm{ng} / \mathrm{mL})$, but not for FSH and prolactin. Female rabbits that did not lactate and females on day 18 of lactation showed higher LH levels and prolactin concentrations than on days 11 and 25 of lactation. 


\section{International Journal of Current Science Research and Review}

ISSN: 2581-8341

Volume 04 Issue 12 December 2021

DOI: 10.47191/ijcsrr/V4-i12-13, Impact Factor: 5.825

IJCSRR@ 2021

www.ijjcsrr.org

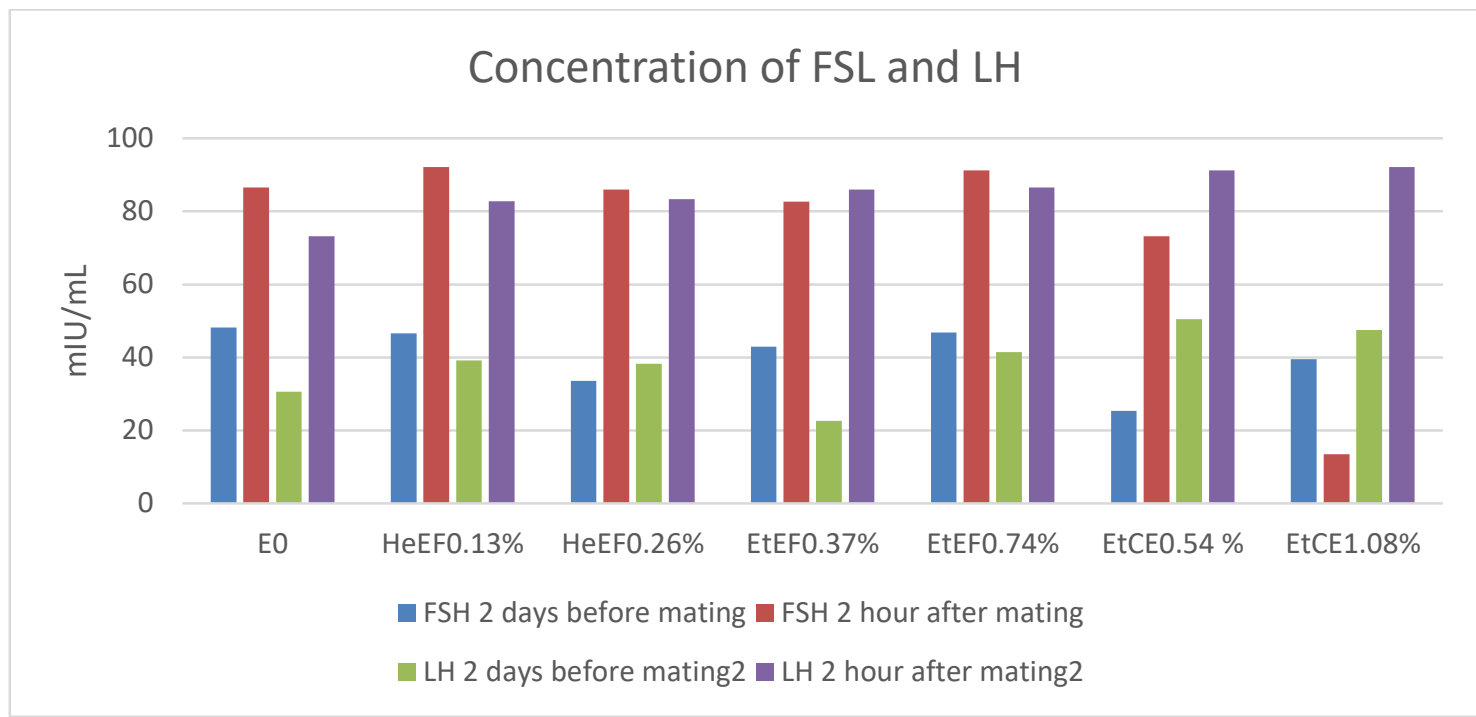

Figure 2. Level of LH and FSH and Litter size

Rabbit does with high ovulation rates ( $>15$ ova), implantation of embryos ( $>12$ embryos), and LS (> 8 children) show higher LH concentrations $(15.1,14.9,15.5 \mathrm{ng} / \mathrm{ml}$, respectively) than the ones with low ovulation rates and litter size (11.1, 9.6 and $9.7 \mathrm{ng}$ $/ \mathrm{mL}$, respectively).

FSH level in the blood relates to ovulation rate and litter size. Both FSH and LH are hormones secreted by hyphophisa and stimulate ovarian activity. The concentration of LH in the plasma slightly before the mating determines the ovulation rate, embryo implantation and litter size. FSH concentration affects ovulation and litter size, while prolactin concentration only affects ovulation level.

The lowest litter size was $5.5 \pm 2.08$ and the highest was $6.75 \pm 2.98$. This may be related to FSH level before mating where the effect of treatment had no effect on FSH level. Although in 2 hours after mating, a significant difference in the level of FSH in the EKE treatment $1.08 \%$ and HeEF $0.26 \%$ were confirmed, the litter sizes from the two treatments were not significantly different.

It can be explained that after the development of ovum stimulated by FSH, there are still many factors that affect the ovum to become fetus including the rate of ovulation, successful fertilization, implantation and pregnancy for 30-31 days. However, those processes were not discussed in this study.

Litter sizes in all treatments were not significantly different which might also be due to LH levels 2 hours after mating that were not significantly different. LH levels in the plasma when close to mating time determine the level of ovulation, implantation of the embryo and litter size [21].

The birth weight and litter weight in this study were not significantly different due to the fact that during pregnancy there was no administration of Moringa leaf flour extract and all test animals consumed the same feed, namely TE (without extract / control). This was done to avoid the side effects of phytoestrogens in pregnant cattle. Pregnancy time ranges between 30 to 31 days and it was not significantly different in all treatments.

\section{CONCLUSION AND SUGGESTION}

Moringa extract administration affects steroid hormones such as estradiol. The administration of moringa leaf extracts using different solvents decreased the level of cholesterol, yet it increased the estradiol level 2 hour before mating which increased the readiness to mate among rabbit does. However, the administration of the moringa extract did not significantly affect the FSH and LH level and litter size in rabbit does. It is recommended that Moringa extract be given before the rabbits mate to stimulate of estrus.

\section{ACKNOWLEDGMENTS}

This study was been financed by the Indonesian Agency for Agricultural Research and Development Ministry. 


\section{International Journal of Current Science Research and Review}

ISSN: 2581-8341

Volume 04 Issue 12 December 2021

DOI: 10.47191/ijesrr/V4-i12-13, Impact Factor: 5.825

IJCSRR@ 2021

www.ijjcsrr.org

\section{REFERENCES}

1. Ryokkynen, A., 2006. Effects of Phytoestrogens on Reproduction and Weight Regulation of Mammals. Dissertations in Biology. . University of Joensuu; 13-21.

2. Potocka, W.B., C. Mannelli, D. Boruszewska, I. Lowalczyk-Zieba, T. Wasniewski, and D. J. Skarzynski. 2013. Diverse Effects of Phytoestrogens on the Reproductive Performance: Cow as a Model. nternational Journal of Endocrinology. Volume 2013, Article ID 650984, http://dx.doi.org/10.1155/2013/650984

3. Pawiroharsono, S. 2001. Prospekdan ManfaatIsoflavonuntuk Kesehatan. Direktorat Teknologi Bioindustri, Badan PengkajiandanPenerapanTeknologi; 1-8. https://www.scribd.com/doc/117479146/Prospek-Dan-Manfaat-Isoflavon-Untuk-Kesehatan. 12 Pebruari 2016

4. Mutiara, K.T, Harijono, T. Estiasih, E.S. Wahyuni. 2013. Effect LactagogueMoringa Leaves (MoringaoleiferaLam) Powder in Rats White Female Wistar, J. Basic. Appl. Sci. Res., 3(4)430-434.

5. Karthivashan, G., P. Arulselvan, A.R. Alimon, I.S. Ismail, and S.Fakurazi. 2015. Competing Role of Bioactive Constituents in Moringaoleifera Extract and Conventional Nutrition Feed on the Performance of Cobb 500 Broilers, BioMed Research International 2015; .Hindawi Publishing Corporation. Doi:10.1155/2015/970398

6. Setiasih, Wahjuningsih Sri, Winarsih Sri, Soetantob Hendrawan, 2019. The Effects Of Adding MoringaOleifera Leaves Extract On Rabbit Does' Milk Production And Mammary Gland Histology. Rjoas, 8(92), August 2019. Doi 10.18551/Rjoas.2019-08.34: 296-304

7. Fahey, J.W. 2005. Moringaoleifera: A Review of the Medical Evidence for Its Nutritional, Therapeutic, and Prophylactic Properties. Part 1, Johns Hopkins School of Medicine, Department of Pharmacology and Molecular Sciences, Lewis B. and Dorothy Cullman Cancer Chemoprotection Center, 725 N. Wolfe Street, 406 WBSB, Baltimore, Maryland, USA 21205-2185.

8. Estrella, MCP., M.D., Jacinto Blas V., Mantaring III, M.D., G.Z. David, M.D., Michelle A. Taup, M.D. 2000. A Doubleblind, Randomized controlled trial on the use of malunggay (Moringaoleifera) for augmentation of the volume of breastmilk among non-nursing mothers of paterm infants, Galacto.Com. Philippine Journal Pediatry49: 3-6.

9. Ola S.I., O.S. Williams, I.A. Obamojure, A.M. Okunlola, 2012. Sexual Receptivity And Conception Rate Of Rabbit Does Fed Selected Perennial Forages In Ile-Ife, Nigeria. Proceedings 10 Th World Rabbit Congress - September 3 - 6, 2012 Sharm El-Sheikh-Egypt, 291 - 295

10. Nath, D., N. Sethi, R.K. Singh, A.K. Jain, 1992. Commonly Used Indian Abortifacient Plants with Special Reference to Their Teratologic Effect in Rats. Journal of Ethnopharmacology 36 (2); 147-154.

11. Raj, A., A.Singh., A. Sharma, N. Singh, P. Kumar, V.Bhatia. 2011. Antifertility Activity of Medicinal Plants on Reproductive system of Female Rat. International Journal of Bio-Engineering Sciences \& TechnologyIJBEST.http://technicaljournals.org. 2 (3): 44-50. 4 Maret 2015.

12. Alemede, I.C., E.A. Onyeji, D.N. Tsado, E.L. Shiawoya. 2014. Reproductive Response of Rabbits Dose To Diets Containing Varying Levels of Horseradish (Moringa oleifera) Leaf Meal, Journal of Biology, Agriculture and Healthcare. ISSN 2224-3208 (paper) ISSN 2225-093X (online). 4 (19) :62-68, 22 Mei 2015.

13. Ayodele, A.E., J.R. Adeola, A.T. Mayowa. 2014. Reproductive Performance of Rabbit Does Fed Graded Levels of MoringaOleifera Leaf Meal Based Diet, International Journal of Science.(3): 49-53

14. Ara, N., Rashid, M. and Amran, M.S. 2008. Comparison of Moringa oleifera Leaves Extract with Atenolol on Serum triglyceride, Serum Cholesterol, Blood glucose, heart weight, body weight in Adrenaline Induced Rats. Saudi J. Biol. Sci., 15, 253-258.

15. Asiedu-Gyekye, I.J, S Frimpong-Manso, C. Awortwe, D.A. Antwi, and A.K. Nyarko. 2014. Micro- and Macroelemental Composition and Safety Evaluation of the NutraceuticalMoringaOleifera Leaves, Journal of Toxicology 2014. HindawiPublishing Corporation: 786979. doi:10.1155/2014/786979.

16. Nguyen, T.T, 1999. The Colesterol-lowering Action of Plant Stanol Esters. American Society for Nutritional Science.129: $2109-2112$.

17. Yu-Yang, R., L. Chang, J. Hsu, B.B.C.Weng, M.C. Palada, M.L. Chadha and V. Levasseur, 2006. Nutritional and Functional Properties of Moringa Leaves- FromGermplasm, to Plant, to Food, to Health. Moringa and other highly 


\section{International Journal of Current Science Research and Review}

ISSN: 2581-8341

Volume 04 Issue 12 December 2021

DOI: 10.47191/ijesrr/V4-i12-13, Impact Factor: 5.825

IJCSRR@ 2021

www.ijcsrr.org

nutritious plant resources: Strategies, Standards and Markets for a Better Impact on Nutrition in Africa. Accra, Ghana, November 16-18, 22.

18. Berne, R.M., M.N. Levi. 1990. Priciples of Physiology. USA C.V. Mosboy Co; 122-178

19. Lilibeth, A.C. and L.P. Glorina, 2010. Effects Moringaoleifera lam (Moringaceac) on The Reproduction of Male Mice (musmusculus), J. Med. Plant Res. 4(12): 115-121.

20. Lebas, F, P. Coudert, R. Rouvier, H. de Rochambeau, 1986. The Rabit. Husbandry, Health and production. Food and Agriculyural Organization of United Nations. Rome; 21-65

21. Saleh, A.M., 2013. Histological Study Of Ovary Through Last Periods (Oryctolagus Cuniculus) Of Pregnancy In Domestic Rabbit. Veterinary Medical Sciences Vol. (4) 11-19

22. Gómez, R.B., PCM. Becerril, H.G. Torres, and M.A Pro. 2004. Relationship among Feeding Level, Change of Cage and Fasting with Vulva Color and Sexual Receptivity in New Zealand White and Californian Nulliparous Does., Proceedings of the 8th World Rabbit Congress, no. 1978: 270-275.

23. Roland, W.S.U.,. R.J. Gouka, H. Gruppen, M. Driesse, L. van Buren, G. Smith and J. Vinken, 2014. 6-Methoxyflavanones as Bitter Taste Receptor Blockers for hTAS2R39. PLOS one. (9) : 1-10

24. Rosenthal, K. 2002. Blood Chemistry Ranges of Rabbits. Universiyy of Pennsylvania of Veterinary Medicine Faculty. www. Mey, 10, 2017; 1-3

25. Xinmei, X., X. Ning, H. Jianbin. 2015. Physiological Function of Phytosterol and Its Application. Animal Husbandry and Feed Science 7 (2): 67-69. doi:10.1007/s13398-014-0173

Cite this Article: Setiasih, Sri Wahjuningsih, Sri Winarsih, Hendrawan Soetanto (2021). The Concentrations of Cholesterol and Reproduction Hormones in Serum of Rabbits Doe That Consumed Moringa oleifera Leaf Extracts. International Journal of Current Science Research and Review, 4(12), 1697-1703 